Utah State University

DigitalCommons@USU

1979

\title{
Interacting environmental factors associated with the incidence of hypoxylon canker on trembling aspen
}

R.I. Bruck

Follow this and additional works at: https://digitalcommons.usu.edu/aspen_bib

Part of the Forest Sciences Commons

\section{Recommended Citation}

Bruck, R.I., "Interacting environmental factors associated with the incidence of hypoxylon canker on trembling aspen" (1979). Aspen Bibliography. Paper 4696.

https://digitalcommons.usu.edu/aspen_bib/4696

This Article is brought to you for free and open access by the Aspen Research at DigitalCommons@USU. It has been accepted for inclusion in Aspen Bibliography by an authorized administrator of DigitalCommons@USU. For more information, please contact

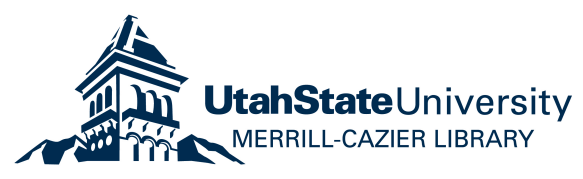




\title{
Interacting environmental factors associated with the incidence of Hypoxylon canker on trembling aspen ${ }^{1}$
}

\author{
Robert I. BruCk ${ }^{2}$ and Paul D. Manion \\ Department of Forest Botany and Pathology, State University of New York College of Environmental Science and Forestry, \\ Syracuse, NY, U.S.A. 13210
}

Received March 6, $1978^{3}$

Accepted October 29, 1979

BRUCK, R. I., and P. D. MANION. 1980. Interacting environmental factors associated with the incidence of Hypoxylon canker on trempling aspen. Can. J. For. Res. 10: 17-24.

Twenty-three natural stands of trembling aspen (Populus tremuloides Michx.) were surveyed for incidence of a canker caused by Hypoxylon mammatum (Wahl.) Miller. Canker incidence ranged from 0 to $70 \%$. Horizonal soil samples were analyzed for their chemical and physical properties, and aspen leaf lamina tissue was analyzed for nutrient concentrations. A model accounting for $92 \%$ of the variation in canker incidence was constructed, utilizing 56 measured parameters, through the use of simple- and multi-correlation statistical analyses. Highly significant negative correlations were observed between canker frequency and each of aspen cover density, soil moisture, abundance of soil mottles, soil consistence, exchangeable soil $\mathrm{Mn}, \mathrm{Ca}$, and $\mathrm{Na}$, and aspen tissue concentrations of $\mathrm{Mn}, \mathrm{Ca}$, and $\mathrm{Na}$. Positive correlations were observed between canker incidence and

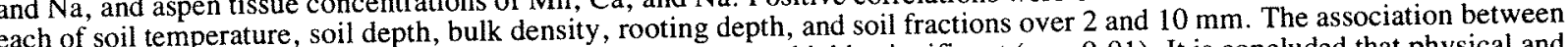
exchangeable soil nutrients and aspen tissue concentrations was highly significant $(p=0.01)$. It is concluded that physical and chemical parameters of the soil which related most directly to moisture comprise a system of variables which are highly related to Hypoxylon canker incidence in trembling aspen.

BRUCK, R. I., et P. D. MANION. 1980. Interacting environmental factors associated with the incidence of Hypoxylon canker on trembling aspen. Can: J. For. Res. 10: 17-24.

Le chancre causé par Hypoxylon mammatum (Wahl.) Miller a été inventorié dans 23 peuplements naturels de peuplier fauxtremble (Populus tremuloides Michx.). La proportion des tiges affectées par le chancre variait de $0 \%$ à $70 \%$. Les caractéristiques tremble (Populus tremues du sol furent déterminées à partir d'échantillons prélevés dans chacun des horizons du sol. Des analyses chimiques et physiques du sol furent déterminees a partir d'échantillons prélevés dans chacun des ériles. Enfin, des analyses statistiques foliaires ont ser a àles et multiples ont permis de bâtir un modèle mathématique incorporant 56 paramètres mesurés sur le de corrélations simples et multiples ont permis de bâtir un modéle mans la fréquence du chancre hypoxylonien. Une corrélation négative chancre et la densité du couvert, l'humidité du sol, l'abondance des marbrures très forte a été calule dans le sol, la consistance du sol, le $\mathrm{Mn}$, Ca et $\mathrm{Na}$ échange apparente du sol, la profondeur de l'enracinement et les fractions les feuilles. La température, la profondeur et la densite apparente du sol, la profondeú de lenracinement La concentration granulométriques du sol au-dessus de 2 et $10 \mathrm{~mm}$ étaient positivement correlees avec la fréquence du chancre. La concentu des éléments minéraux dans les feuilles était très significativement reliée à la concentration des élements échangeables so $(p=0.01)$. En conclusion, les paramètres chimiques et physiques du sol qui ont une incidence directe sur lhumiditremble. constituent un ensemble de variables étroitement reliées à la fréquence du chancre hypoxylonien chez le praduit par le journal]

The diffuse canker caused by the ascomycete Hypoxylon mammatum (Wahl.) Miller ( $=H$. pruinatum (Klotzche) Cke.) on trembling aspen (Populus tremuloides Michx.) was first described in 1924; however, Koch's postulates were not established until 1940 (4). Although the disease has been the subject of over 30 years of investigation, many questions concerning the pathogen's life cycle remain unanswered.

Disease relationships involving environmental and stand factors have been recognized. Fewer cankers occurred in mature stands than in younger ones $(1,2,4$, 9 , 14). Mortality was higher on trees growing on "poorer" sites as compared with those on "good" ones $(9,11)$. Dense stands had lower canker incidence than

\footnotetext{
'Portion of a thesis submitted by R.I.B. in partial fulfillment of the requirements for the Ph.D. degree.

2Present address: Department of Plant Pathology, North Carolina State University, Raleigh, NC, U.S.A. 27650.

${ }^{3}$ Revised manuscript received October 26, 1979.
}

open or sparsely stocked stands $(5,11)$. Bagga and Smalley (3) using potted seedlings found that moisturestressed and unfertilized low vigor plants were more susceptible to $H$. mammatum cankering.

In contrast to the observations of others, Anderson (1) found no correlation between canker incidence and each of site index (SI), site history, tree vigor, and the height of the soil water table.

Due to the lack of previous intensive sampling to describe the role of the environmental complex on the incidence and expression of Hypoxylon canker in the field, a study was initiated in 1974 to elucidate the role of interacting site properties and their association with the frequency of Hypoxylon cankers on trembling aspen in a limited geographic area of New York.

\section{Materials and methods}

Twenty-three natural clonal stands of trembling aspen were located on a 7 square mile level tract $\left(1 \mathrm{mi}^{2}=2.589 \mathrm{~km}^{2}\right)$ on 
TABLE 1. Correlations of aspen stand properties with Hypoxylon frequency

\begin{tabular}{lccc}
\hline \hline Stand property & $\begin{array}{l}\text { Correlation } \\
\text { coefficient }\end{array}$ & Mean & $\begin{array}{c}\text { Standard } \\
\text { deviation }\end{array}$ \\
\hline Aspen cover & $-0.930^{* *}$ & $61.52 \%$ & 21.02 \\
Site index & -0.200 & 72.60 & 6.88 \\
Age of dominant & -0.190 & 19.16 years & 2.28 \\
Height of dominant & -0.222 & $17.48 \mathrm{~m}$ & 3.00 \\
Slope of site & -0.102 & $8.69 \%$ & 2.94 \\
\hline
\end{tabular}

$*_{r}=0.404$ at $5 \% ; *_{r}=0.515$ at $1 \%$.

${ }^{a}$ Site index based on Gevorkiantz (8), SI at 50 years.

the southwestern fringe of the Tug Hill Plateau of central New York. The criterion for stand selection was the presence of a minimum of fifty $9-\mathrm{cm}$-diameter at breast height $(\mathrm{dbh})$ aspen stems. A total of 2345 trees were individually examined for symptoms of Hypoxylon canker. Site index (8), percentage of slope, and stand factors (height, age, and diameter of dominants and aspen crown cover (density)) were recorded.

A soil pit was excavated at each site and all discernible horizons were sampled down to the parent material stratum (a total of 96 samples). The following morphological soil parameters were assessed: total soil depth, solum horizon classification, horizon depth, soil color, presence of mottles and coatings, soil texture, structure, consistence, presence and depth of roots, and contexture of horizonal boundaries (15).
Soil bulk density was determined (in situ) in brass rings of known volume. Soil temperature and total (gravimetric) moisture were sampled weekly throughout the growing season. In the laboratory each soil sample was sieved to separate fractions $10 \mathrm{~mm}$ and above, $2-10 \mathrm{~mm}$, and less than $2 \mathrm{~mm}$. The lessthan-2-mm fraction was subjected to physical and chemical analysis. Soil moisture retention was calculated at 0.33 and 15 bars $(1 \mathrm{bar}=100 \mathrm{kPa})$ atmospheric pressure. Soil reaction was determined electrometrically, and particle size distribution (texture) was determined by the hydrometer jar method. Organic matter and organic carbon were assessed by loss on ignition and by wet oxidation. Extractable $P$ and exchangeable major and minor cations were analyzed spectrophotometrically (19).

TABLE 2. Correlations of soil physical properties with Hypoxylon frequency

\begin{tabular}{|c|c|c|c|}
\hline Soil property & $\begin{array}{l}\text { Correlation } \\
\text { coefficient }\end{array}$ & Mean & $\begin{array}{r}\text { Standard } \\
\text { deviation }\end{array}$ \\
\hline \multicolumn{4}{|l|}{ Total soil sample } \\
\hline Soil temperature ${ }^{a}$ & $+0.966^{* *}$ & $16.16^{\circ} \mathrm{C}$ & 5.32 \\
\hline Soil depth & $+0.757 * *$ & $62.35 \mathrm{~cm}$ & 15.68 \\
\hline Mottles $^{b}$ & $-0.849 * *$ & 1.26 & 1.05 \\
\hline Over $2 \mathrm{~mm}$ & $+0.822 * *$ & $16.27 \%$ & 10.32 \\
\hline Over $10 \mathrm{~mm}$ & $+0.827 * *$ & $9.46 \%$ & 4.94 \\
\hline Consistence $^{r}$ & $-0.816^{* *}$ & 1.67 & 1.25 \\
\hline Root depth & $+0.754 * *$ & $31.47 \mathrm{~cm}$ & 15.50 \\
\hline \multicolumn{4}{|l|}{$A+B$ Horizons } \\
\hline Gravimetric moisture $^{a}$ & $-0.939 * *$ & $32.38 \%$ & 17.57 \\
\hline Moisture at $0.33 \mathrm{bar}$ & $-0.871 * *$ & $7.23 \%$ & 2.25 \\
\hline Moisture at 15 bar & $-0.841 * *$ & $2.82 \%$ & 1.68 \\
\hline Organic matter & $-0.719^{* *}$ & $6.23 \%$ & 4.01 \\
\hline Organic carbon & $-0.717 * *$ & $4.92 \%$ & 3.09 \\
\hline Loss on ignition & $-0.869 * *$ & $5.99 \%$ & 2.44 \\
\hline Silt + clay & $-0.811 * *$ & $16.20 \%$ & 8.49 \\
\hline Bulk density & $+0.953 * *$ & $0.92 \mathrm{~g} / \mathrm{cm}^{3}$ & 0.27 \\
\hline \multicolumn{4}{|l|}{ C Horizon } \\
\hline Gravimetric moisture ${ }^{a}$ & $-0.598 * *$ & $22.75 \%$ & 7.12 \\
\hline Moisture at $0.33 \mathrm{bar}$ & $-0.472^{*}$ & $3.79 \%$ & 1.13 \\
\hline Moisture at 15 bar & $-0.573 * *$ & $1.35 \%$ & 0.72 \\
\hline Organic matter & -0.217 & $1.94 \%$ & 0.95 \\
\hline Organic carbon & -0.219 & $1.40 \%$ & 0.92 \\
\hline Loss on ignition & -0.392 & $1.76 \%$ & 1.01 \\
\hline Silt + clay & $-0.562 * *$ & $6.73 \%$ & 2.13 \\
\hline Bulk density & $+0.674 * *$ & $1.54 \mathrm{~g} / \mathrm{cm}^{3}$ & 0.98 \\
\hline
\end{tabular}

$*_{r}=0.404$ at $5 \% ; * *_{r}=0.515$ at $1 \%$.

${ }^{a}$ Measured weekly throughout growing season, means are seasonal averages.

${ }^{b}$ Synthetic mottle scale, from 0 , no mottles, to 3 , mottles abundant.

'Synthetic consistence scale, from 0 , very friable, to 4 , very firm. 


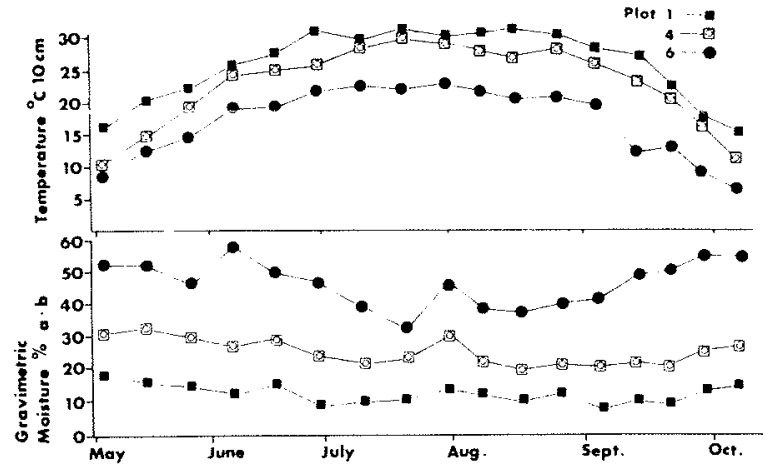

FIG. 1. Growing season soil temperature (at $10 \mathrm{~cm}$ ) and percentage of gravimetric moisture (on a per weight basis) for surface strata of three aspen sites.

Inter-plot simple- and multi-correlation statistical analyses were conducted. Programs and subprograms for linear regression, multiple regression, and factor analysis were employed. Nonparametric variables were tested for suitability via Spearman rank correlation and were found not to violate the assumption that they are linear (12).

\section{Results}

Site and stand factors

Aspen cover based on crown closure (a reflection of stand density) was highly negatively correlated with $H$. mammatum incidence. The variables (percentage of slope, age of dominant, height of dominant, and site index) were not correlated with canker incidence (Table 1). Little variation on site index among the 23 sites was found, even though soils ranged from rich, moist silt loams to glacial outwash sand and till deficient in exchangeable nutrients and moisture.

\section{Soil physical properties}

Strong positive correlations were nated between canker incidence and each of soil temperature, total soil depth, bulk density, and soil fractions over 2 and 10 $\mathrm{mm}$. Hypoxylon mammatum frequency was negatively correlated with the presence of mottles, soil consistence, gravimetric moisture in surface soils $(A+B$ horizons), organic matter and organic carbon in surface soils, moisture retention in surface soils at 0.33 and 15 bars, and gravimetric moisture in subsoils ( $\mathrm{C}$ horizon) and subsoil moisture retention at 15 bars (Table 2). Soil temperature and gravimetric moisture of three plots with differing canker frequencies are compared in Fig. 1.

Plot 1 with $63 \%$ canker incidence is a glacially deposited outwash sand, plot 4 with $45 \%$ incidence is an agriculturally disturbed silt-loam, and plot $6(0 \%$ canker incidence) occurs on highly organic waterlogged soils resulting from interrupted drainage patterns. The relationship of soil temperature to canker incidence is almost linear in nature $(r=0.966)$. The significance of this correlation may be reflected in the seasonal spectrum of total (gravimetric) soil moisture. The average moisture was $10-15 \%$ (on a per weight basis) in August for plot 1 , whereas at the same sampling time plot 6 averaged $40 \%$. All factors associated with soil drainage, and hence soil moisture and temperature (i.e., soil consistence, organic matter, bulk density, and particle distribution) are significantly intercorrelated in relation to the presence or absence of Hypoxylon canker.

TABLE 3. Correlations of soil chemical properties with Hypoxylon frequency

\begin{tabular}{llrr}
\hline Soil property & $\begin{array}{l}\text { Correlation } \\
\text { coefficient }\end{array}$ & Mean $^{a}$ & $\begin{array}{r}\text { Standard } \\
\text { deviation }\end{array}$ \\
\hline A + B Horizons & & & \\
Soil reaction & $-0.814^{* *}$ & 5.09 & 1.24 \\
CEC & $-0.850^{* *}$ & 118.70 & 33.72 \\
P & $-0.695^{* *}$ & 0.17 & 0.10 \\
$\mathrm{Mn}$ & $-0.712^{* *}$ & 1.93 & 0.38 \\
$\mathrm{Na}$ & $-0.678^{* *}$ & 15.78 & 2.41 \\
$\mathrm{Ca}$ & $-0.630^{* *}$ & 68.47 & 17.85 \\
$\mathrm{Mg}$ & $-0.484^{*}$ & 33.33 & 13.71 \\
$\mathrm{~K}$ & -0.375 & 4.87 & 2.34 \\
$\mathrm{C} \mathrm{Horizon}$ & & & \\
Soil reaction & $-0.512^{*}$ & 4.62 & 1.02 \\
$\mathrm{CEC}$ & $-0.473^{*}$ & 98.63 & 22.14 \\
$\mathrm{P}$ & -0.312 & 0.07 & 0.01 \\
$\mathrm{Mn}$ & $-0.485^{*}$ & 0.97 & 0.08 \\
$\mathrm{Na}$ & -0.231 & 1.93 & 0.91 \\
$\mathrm{Ca}$ & $-0.473^{*}$ & 77.50 & 29.79 \\
$\mathrm{Mg}$ & -0.258 & 30.83 & 5.79 \\
$\mathrm{~K}$ & -0.132 & 9.31 & 3.40 \\
\hline
\end{tabular}

$*_{r}=0.404$ at $5 \% ; * *_{r}=0.515$ at $1 \%$.

${ }^{a}$ Exchangeable soil nutrients in mequiv/100 g soil. 
TABLE 4. Correlations of aspen tissue nutrients with Hypoxylon frequency

\begin{tabular}{cccc}
\hline Tissue nutrient & $\begin{array}{l}\text { Correlation } \\
\text { coefficient }\end{array}$ & Mean $^{a}$ & $\begin{array}{c}\text { Standard } \\
\text { deviation }\end{array}$ \\
\hline $\mathrm{P}$ & $-0.942^{* *}$ & 0.31 & 0.12 \\
$\mathrm{~K}$ & $-0.728^{* *}$ & 0.60 & 0.20 \\
$\mathrm{Mg}$ & $-0.902^{* *}$ & 0.38 & 0.18 \\
$\mathrm{Ca}$ & $-0.742^{* *}$ & 1.19 & 0.68 \\
$\mathrm{Na}$ & $-0.871^{* *}$ & 0.02 & 0.01 \\
$\mathrm{Mn}$ & $-0.875^{* *}$ & 0.04 & 0.02 \\
\hline
\end{tabular}

$*_{r}=0.404$ at $5 \% ; * * r=0.515$ at $1 \%$.

${ }^{a}$ Concentration in percentage of tissue dry weight.

\section{Soil chemical properties}

All the soil chemical properties of the surface strata except exchangeable $\mathrm{Mg}$ and $\mathrm{K}$ were highly negatively correlated with the presence of $H$. mammatum (Table 3). Cation exchange capacity (CEC) in surface soils exhibited the highest simple correlation loading $(r=-0.850) . \mathrm{Mg}$ in surface soils and $\mathrm{Mn}$ and $\mathrm{Ca}$ in the subsoil horizon were negatively correlated with Hypoxylon canker at the $5 \%$ level of confidence.

Aspen foliage analysis

Highly significant negative correlations were calculated for six plant nutrients from aspen leaf tissue and $H$. mammatum (Table 4). Correlations between soil nutrients and aspen foliage concentrations further proved to be highly positively correlated (Table 5). When foliage analysis on the $H$. mammatum-infected trees was conducted, highly significant negative correlations were also noted with canker incidence; however, concentrations and correlations were lower than those of nondiseased individuals (Table 6). These differences occurred even though the diseased trees that were sampled appeared to have healthy vigorous=crowns.

\section{Multivariate analysis}

A factor analysis was conducted on three sets of variables. Factor analysis enables the user to discern whether underlying patterns or relationships exist in a
TABLE 5. Simple coefficients of correlation between soil chemical variables and aspen tissue nutrient concentrations

\begin{tabular}{cc}
\hline \hline Soil/tissue nutrient & Correlation coefficient \\
\hline $\mathrm{K}$ & $+0.817^{* *}$ \\
$\mathrm{Ca}$ & $+0.896^{* *}$ \\
$\mathrm{Mg}$ & $+0.852^{* *}$ \\
$\mathrm{Mn}$ & $+0.979^{* *}$ \\
$\mathrm{Na}$ & $+0.798^{* *}$ \\
$\mathrm{P}$ & $+0.780^{* *}$ \\
\hline
\end{tabular}

$*=0.404$ at $5 \% ; * * r=0.515$ at $1 \%$.

data matrix. From an intercorrelation matrix, data may be rearranged and reduced to a smaller set of source variables or factors accounting for the observed interrelations (12).

Due to the large number of variables, 56 , in this study, the factor analysis was divided into three subgroups: physical parameters, chemical parameters, and a combination analysis employing the strongest chemical and physical factor loadings. An iterative three or four factor solution, varimax (orthogonal) rotated " $R$ "' type factor analysis was employed in each case. Other rotation techniques failed to strengthen the acquired factor loadings:

Eleven physical parameters plus $H$. mammatum incidence were reduced to three factors (Table 7). The first factor elucidates a particle size or textural variable. The

TABLE 6. Correlations of "diseased" aspen tissue nutrients with Hypoxylon frequency

\begin{tabular}{cccc}
\hline \hline Tissue nutrient & $\begin{array}{l}\text { Correlation } \\
\text { coefficient }\end{array}$ & Mean $^{a}$ & $\begin{array}{c}\text { Standard } \\
\text { deviation }\end{array}$ \\
\hline $\mathrm{P}$ & $-0.843^{* *}$ & 0.26 & 0.18 \\
$\mathrm{~K}$ & $-0.611^{* *}$ & 0.51 & 0.13 \\
$\mathrm{Mg}$ & $-0.674^{* *}$ & 0.29 & 0.09 \\
$\mathrm{Ca}$ & $-0.597^{* *}$ & 0.61 & 0.24 \\
$\mathrm{Na}$ & $-0.619 * *$ & 0.02 & 0.01 \\
$\mathrm{Mn}$ & $-0.812^{*}$ & 0.03 & 0.01 \\
\hline
\end{tabular}

$* r=0.404$ at $5 \% ; * * r=0.515$ at $1 \%$.

${ }^{n}$ Concentration in percentage of tissue dry weight.

TABLE 7. Varimax (orthogonal) rotated factor analysis, conducted on 11 physical soil variables

\begin{tabular}{lrrrc}
\hline \hline Variable & Factor 1 & Factor 2 & Factor 3 & \multicolumn{1}{c}{$h^{2}$} \\
\hline$H$. mammatum & -0.57 & -0.62 & -0.53 & 0.88 \\
Total soil depth & -0.15 & -0.95 & -0.24 & 0.99 \\
Soil mottles & 0.49 & 0.33 & 0.68 & 0.76 \\
Fraction over 2 mm & -0.93 & -0.18 & -0.41 & 0.89 \\
Consistence & 0.32 & 0.30 & 0.87 & 0.88 \\
Root depth & -0.36 & -0.80 & -0.30 & 0.85 \\
SurSoil moisture & 0.55 & 0.48 & 0.69 & 0.95 \\
SurSoil 15 bars & 0.53 & 0.29 & 0.70 & 0.84 \\
SurSoil organic & 0.57 & 0.57 & 0.38 & 0.80 \\
SurSoil silt + clay & 0.54 & 0.54 & 0.46 & 0.79 \\
SurSoil bulk density & -0.77 & -0.41 & -0.47 & 0.92 \\
SurSoil temperature & -0.69 & -0.58 & -0.44 & 0.93 \\
\hline
\end{tabular}


TABLE 8. Varimax (orthogonal) rotated factor analysis, conducted on 12 surface soil (SurSoil) and aspen tissue variables

\begin{tabular}{lrrrrc}
\hline Variable & Factor 1 & Factor 2 & Factor 3 & Factor 4 & $h^{2}$ \\
\hline$H$. mammatum & -0.51 & -0.58 & -0.53 & -0.61 & 0.99 \\
SurSoil CEC & 0.46 & 0.69 & 0.49 & 0.22 & 0.83 \\
SurSoil reaction & 0.78 & 0.22 & 0.19 & 0.20 & 0.69 \\
SurSoil P & 0.18 & 0.37 & 0.02 & 0.87 & 0.84 \\
SurSoil Mn & 0.69 & 0.53 & 0.44 & 0.16 & 0.90 \\
SurSoil Na & 0.17 & 0.71 & 0.25 & 0.35 & 0.77 \\
SurSoil Ca & 0.33 & 0.80 & 0.32 & 0.29 & 0.91 \\
Tissue P & 0.56 & 0.43 & 0.46 & 0.49 & 0.96 \\
Tissue Mn & 0.69 & 0.55 & 0.43 & 0.13 & 0.90 \\
Tissue Na & 0.38 & 0.35 & 0.77 & 0.23 & 0.86 \\
Tissue Ca & 0.36 & 0.79 & 0.31 & 0.26 & 0.84 \\
Tissue Mg & 0.25 & 0.52 & 0.69 & 0.34 & 0.88 \\
Tissue K & 0.14 & 0.18 & 0.67 & 0.01 & 0.55 \\
\hline
\end{tabular}

expression of the high factor loadings of soil fraction over $2 \mathrm{~mm}$, surface soil bulk density, and soil temperature demonstrates high covariance among these variables. Factor 2 describes the strong correlation between soil depth and root penetration. In deep, coarse, sandy soils, roots exhibited maximum penetration. Shallow soils that were commonly interrupted by fragipans expressed poor root penetration. Canker incidence loads highest on factor 2 ; however, the differences in $H$. mammatum loadings across the three factors is insignificant. On factor 3 the variables surface soil moisture retention at 15 bars, soil mottles, and consistence all exhibit high factor loadings. This combination of high moisture, firm soil, and the condition of imperfectly drained soil exhibiting pockets of oxidized and reduced material (mottles) all add support to the negative correlations that are derived from these variables with canker frequency. The communality $\left(h^{2}\right)$ of all the variables across the three factors is generally strong. The lack of very high loadings on $H$. mammatum infers that no single variable plays a unique role in disease incidence.

A four factor terminal solution was called for in the chemical parameter factor analysis (Table 8). Only surface soil (SurSoil) nutrients were employed in this analysis due to their higher coefficient $(r)$ loadings as compared to the subsoil horizons. All the soil and tissue variables are negatively correlated with canker incidence.

In factor 1 , soil reaction and soil and tissue $\mathrm{Mn}$ concentrations were extracted as the highest factor loadings. Mn exchange capacity in the soil and the reflection of this variable in tissue concentrations represent a colinear parameter which is negatively correlated with the incidence of $H$. mammatum.

Factor 2 is characterized by a high tissue $\mathrm{Ca}$ concentration loading together with high soil $\mathrm{Ca}$ and $\mathrm{Na}$ exchange coefficients. Cation exchange capacity (CEC) also contributes to the covariance of factor 2 . The relatively high factor loadings for all exchangeable cations may be indicative of the high CEC loadings. The $\mathrm{K}, \mathrm{Mg}$, and $\mathrm{Na}$ exchange values are all highly colinear. The strength of the total CEC is indicative of the relationship between exchangeable soil nutrients and the ensuing plant uptake.

Factor 4 expressed only one significant variable in relation to a relatively high canker incidence loading. The independently sorted variable surface soil $\mathrm{P}$ is statistically described; however, an autonomous explanation for this separation has not been found. The relationship between $P$ bound in organic systems and its factor segregation may be postulated.

Following the physical and chemical factor analyses a combination factor analysis was performed utilizing those variables in each analysis that expressed the most significant factor loadings. Table 9 lists 12 chemical and physical variables together with canker incidence that were tested in the combination factor analysis.

Factor 1 describes two specific interrelations. Exchangeable soil $\mathrm{Ca}$ and $\mathrm{Mn}$ with foliage $\mathrm{Ca}$ and $\mathrm{Mn}$ concentrations form a strong nutrient cofactor. Hypoxylon mammatum incidence loads highest on factor 2 . A physical soil moisture and textural solution is described in this factor. Fraction over $2 \mathrm{~mm}$ and surface soil bulk density are highly negatively correlated with surface soil moisture retention at 15 bars. The strong positive association of the soil moisture factor with canker incidence emphasizes the importance of moisture in the etiology of Hypoxylon canker.

Factor 3 indicates the relationship between soil depth and root depth. Extractable surface soil $P$ again independently sorts on this factor column. The communality of $H$. mammatum $(0.99)$ across the three factors again indicates that no single variable represents a source parameter in accounting for canker frequency.

\section{Discussion}

Trembling aspen occupies an extraordinarily wide range of climate, altitude, and soil conditions. Aspen is 
TABLE 9. Combination physical and chemical varimax (orthogonal) rotated factor analysis conducted on 12 total and surface soil and aspen tissue variables

\begin{tabular}{lcccc}
\hline \hline Variable & Factor 1 & Factor 2 & Factor 3 & $h^{2}$ \\
\hline$H$. mammatum & -0.49 & -0.67 & -0.56 & 0.99 \\
Fraction over 2 mm & -0.40 & -0.74 & -0.23 & 0.76 \\
SurSoil bulk density & -0.31 & -0.84 & -0.44 & 0.99 \\
Total soil depth & -0.39 & -0.15 & -0.84 & 0.88 \\
Root depth & -0.35 & -0.36 & -0.80 & 0.89 \\
Consistence & 0.51 & 0.60 & 0.17 & 0.76 \\
SurSoil 15 bars & 0.54 & 0.76 & 0.18 & 0.91 \\
SurSoil Mn & 0.79 & 0.47 & 0.27 & 0.92 \\
SurSoil Ca & 0.71 & 0.38 & 0.38 & 0.79 \\
SurSoil P & 0.08 & 0.22 & 0.92 & 0.90 \\
Tissue Mn & 0.77 & 0.48 & 0.25 & 0.89 \\
Tissue Ca & 0.79 & 0.28 & 0.38 & 0.85 \\
Tissue Na & 0.51 & 0.69 & 0.19 & 0.79 \\
\hline
\end{tabular}

in fact the most widely distributed and prolific tree species on the North American continent (6).

Many researchers have found associations between site, and aspen growth and vigor. Fralish and Loucks (7) attempted to evaluate models for the assessment of aspen site quality in Wisconsin. Their findings indicated that soil texture, available water holding capacity, water table depth, and stand density are important factors controlling aspen site index. Kittredge (10) was able to correlate soil profile and horizon characteristics to aspen site index, whereas Stoeckeler (16) found textural (silt + clay) relationships to site index, and Voigt et al. (18) observed correlations among site index, $\mathrm{pH}$ of the $\mathrm{A}$ horizon and growth correlations with base saturation, available $\mathrm{P}$, and exchangeable $\mathrm{Ca}$ and $\mathrm{Mg}$. However, in the present study these same variables accounted for very little site-index variation, but are significant factors in the variation of $H$. mammatum frequency.

The spectrum of environmental parameters examined in this study demonstrated little or no correlation to aspen site index or "quality." Trees of even age differed insignificantly with respect to height and dbh (Table 1 ). However, the frequency and proliferation of Hypoxylon canker in these stands differed greatly (range 0-70\%).

Some of the variation in infection incidence may be due to genetic differentiation of susceptibility to infection and (or) invasion (17). The strength of relationships within and among certain environmental parameters measured suggests that in this study area environmental variables are a dominant factor influencing the susceptibility of aspen to cankering.

The data of Day and Strong (5), Povah (13), and Schreiner (14) with respect to greater canker incidence in open (less densely stocked) stands are corroborated in this study. Aspen cover was negatively correlated $(r$ $=-0.930$ ) with canker frequency. With the exception of cover density, classical stand quality parameters failed to demonstrate significant relationships with canker incidence (Table 1).
In sharp contrast to the findings of Anderson (1), site characteristics, i.e., tree vigor (as reflected by nutrient concentrations), available moisture, and soil conditions, were highly correlated with the frequency of Hypoxylon canker in the Tug Hill Plateau sampling area.

Seven soil physical variables that reflect poor moisture availability, e.g., high soil temperature, high bulk density, and abundance of stones and deep sandy soils, were strongly positively correlated $(p=0.01)$ with the incidence of $H$. mammatum. The strong covariance of these variables in the physical factor analysis factor 1 and the combination factor analysis factor 2 corroborate this relationship.

Any factor that contributed to moisture availability and retention was strongly negatively correlated with canker incidence. The strongest-relationship in the physical variable analysis was growing season total moisture data (Fig. 1), observed during 1975. Bägga and Smalley (3) noted that any factor contributing to host moisture stress increased host susceptibility to canker incidence. Bagga and Smalley (3) also noted that fewer cankers were initiated in plants fertilized with a commercial NPK mix, than in those that were unfertilized. Sixteen soil nutrient properties were measured in this study, all of which were negatively correlated with canker frequency in the field (Table 3 ). Surface soil horizon chemical characteristics were more valuable as predictive indicators for $H$. mammatum frequency than were subsoil horizons. Cation exchange capacity, together with exchangeable $\mathrm{Ca}, \mathrm{Mn}$, and $\mathrm{Na}$ in the surface soil are strong predictive chemical variables. High $\mathrm{pH}$ (soil reaction) was also negatively associated with canker incidence. Absence of nutrient leaching and binding, and higher expressed ion availabilities help support this relationship.

Regardless of the availability of these plant nutrients in the regolith, the parameters of texture and available moisture will profoundly affect the accessibility of free ions to plant roots. Correlation coefficients among soil moisture, textural properties, and exchangeable nu- 


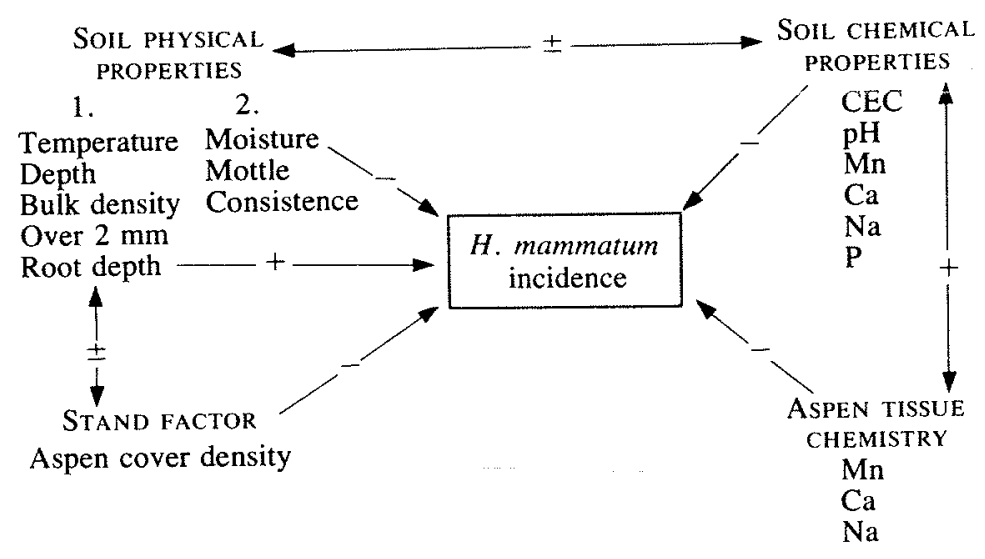

FIG. 2. An interactive model for site evaluation and prediction of predisposition to Hypoxylon cankering based on the combination factor analysis results.

trients are all highly significant $(p=0.01)$. Of the six aspen tissue nutrient concentrations analyzed, all proved to be both highly negatively correlated with canker incidence and highly positively correlated with the same soil nutrient exchange values (Table 5).

The chemical factor analysis illustrates the overall negative correlations between soil and tissue nutrients and canker frequency (Table 8). The strong covariance between soil and foliage corresponding elements may support a theory that availability coupled with accessibility of soil nutrients may be utilized as a predictive indicator for assessing site predisposition to the cankering of aspen by $H$. mammatum. The strength of this relationship warrants further investigation.

The combination physical and chemical parameter factor analysis exhibits an apparent discontinuity in the covariance. The independence of the chemical variables from the physical ones does not infer lack of correlation but simply suggests strong covariance within the individual categories.

Utilizing the four categories: stand factors, soil physical properties, soil chemistry, and aspen foliage chemistry, an interactive model of site predisposition to $\mathrm{Hy}$ poxylon canker is illustrated (Fig. 2). The model elucidates 18 variables (measured in this study) that account for $92 \%$ of the variation in the $H$. mammatum incidence as extracted from the factor analysis correlation matrix.

In Fig. 2, solid lines with a (+) designation illustrate a significant positive correlation between variables within a category and canker incidence, or relationships between categories. A (-) designation signifies a negative interaction. All variables with association arrows demonstrate significant linear correlation coefficients $(p=0.01)$ in relation to canker frequency.

The stand factor category has only one significant variable, aspen cover density. High density is strongly negatively correlated with cankering. Stand density will influence certain soil physical properties, i.e., temperature and moisture evaporation rates. Soil physical properties are divided into two subgroups: (i) positively correlated variables (soil temperature, soil total depth, bulk density, percentage over $2 \mathrm{~mm}$, and root depth), and (ii) negatively correlated variables (with canker frequency; gravimetric moisture, abundance of mottles, and soil consistence).

All variables of the soil chemical property category are strongly negatively correlated with $H$. mammatum frequency. The strong covariance among soil and tissue $\mathrm{Mn}, \mathrm{Ca}$, and $\mathrm{Na}$ make the relative concentrations of these nutrients valuable predictive agents.

This model accounts for a large proportion of the measured canker frequency variation. By assessing the aforementioned set of source factors, environmental predisposition to canker susceptibility may be predicted. Thus canker incidence is not influenced by a single variable, but by an array of quantifiable interacting environmental parameters that may be employed in assessing risk factors in the silvicultural management of trembling aspen.

\section{Acknowledgment}

The authors wish to thank Mr. Donald Bickelhaupt for excellent technical assistance in soil and tissue analysis.

1. Anderson, G. W. 1972. Development of Hypoxylon mammatum canker on artificially shaded aspen stems. For. Sci. 18: 316-318.

2. ANDERSON, R. L. 1952. Factors influencing the incidence of Hypoxylon canker on aspen. Phytopathology, 42: 463 (Abstr.).

3. BagGa, D. K., and E. B. Smalley. 1974. The development of Hypoxylon canker of Populus tremuloides: Role of interacting environmental factors. Phytopathology, 64: 658-662. 
4. BIER, J. E. 1940. Studies in forest pathology. III. Hypoxylon canker of poplar. Can. Dep. Agric. Tech. Bull. No. 27.

5. Day, M. W., and F. C. Strong. 1959. A study of Hypoxylon canker on aspen. Mich. Agric. Exp. Stn. Q. Bull. 41: 870-877.

6. FowElls, H. A. 1965. Silvics of forest trees of the United States. U.S. Dep. Agric. Agric. Handb. No. 271.

7. Fralish, J. S., and O. L. Loucks. 1975. Site quality evaluation models for aspen (Populus tremuloides Michx.) in Wisconsin. Can. J. For. Res. 5: 523-528.

8. Gevorkiantz, S. R. 1956. Site index curves for aspen in the Lakes States. U.S. For. Ser. Lakes States For. Exp. Stn. Tech. Notes No. 464.

9. GRUENHAGEN, R. H. 1945. Hypoxylon pruinatum and its pathogenesis on poplar. Phytopathology, 35: 72-89.

10. KittredGE, J., JR. 1938. The interrelations of habitat, growth rate, and associated vegetation in the aspen community of Minnesota and Wisconsin. Ecol. Monogr. 8: $151-246$

11. Lorenz, R. C., and C. M. Christenson. 1937. A survey of forest tree diseases and their relation to stand improvement in the Lake and Central States. U.S. Dep. Agric. Bur. Plant Ind. Publ. Wash. D.C.

12. Nie, N. H., C. H. Hyll, J. G. Jenkins, K. SteinbrenNER, and D. H. BENT. 1975. SPSS-Statistical package for the social sciences. 2nd ed. McGraw-Hill Inc., New York, NY,

13. Povah, A. 1924. Hypoxylon poplar canker. Phytopathology, 14: 140-145.

14. Schreiner, E. J. 1925. Preliminary survey of Hypoxylon canker in Oxford County, Maine. Mycologia, 17: 218-220.

15. Soll Conservation Service. 1975. Soil survey manual U.S. Dep. Agric. Handb. No. 18.

16. Stoeckeler, J. H. 1960. Soil factors affecting the growth of quaking aspen forests in the Lakes States. Univ. Minn. Agric. Exp. Stn. Tech. Bull. No. 233.

17. Valentine, F. A., P. D. Manion, and K. E. Moore. 1976. Genetic control of resistance to Hypoxylon infection and canker development in Populus tremuloides. Proceedings of the 12th Lake States Forest Tree Improvement Conference. U.S. For. Serv. Gen. Tech. Rep. NC-26 pp. 132-146.

18. Voigt, G. K., M. L. Heinselman, and Z. A. Zasada. 1957. The effect of soil characteristics on the growth of quaking aspen in northern Minnesota. Soil Sci. Soc. Am. Proc. 14: 345-347.

19. Wilde, S. A., G. K. Voigt, and J. G. IYer. 1972. Soil and plant analysis for tree culture. 4th ed. Oxford Pub. House, Calcutta, India. 